\title{
Kepemilikan Manajerial Sebagai Pemoderasi Pengaruh Kinerja Keuangan Terhadap Nilai Perusahaan Pada Perusahaan Consumer Goods Tahun 2015-2018
}

\author{
Hasdi Suryadi \\ STIE Pancasetia Banjarmasin \\ Email: hasdisuryadi@yahoo.com
}

\begin{abstract}
ABSTRAK
Penelitian ini bertujuan untuk menganalisis dan mendapatkan bukti empiris variabel independen yang terdiri dari current ratio, net profit margin, debt to equity ratio, dan total asset turn over mempengaruhi variabel dependen nilai perusahaan secara parsial maupun secara simultan. Dengan variabel moderasi kepemilikan manajerial secara simultan mempengaruhi hubungan current ratio, net profit margin, debt to equity ratio, dan total asset turn over terhadap nilai perusahaan pada perusahaan consumer goods. Analisis dilakukan terhadap 17 perusahaan consumer goods yang telah memenuhi kriteria dalam teknik purposive sampling. Pengujian hipotesis penelitian dilakukan dengan analisis regresi berganda dan analisis regresi moderasi. Hasil penelitian menunjukkan bahwa secara parsial current ratio tidak berpengaruh terhadap nilai perusahaan. Sedangkan net profit margin, debt to equity ratio, dan total asset turn over berpengaruh positif terhadap nilai perusahaan. Secara simultan current ratio, net profit margin, debt to equity ratio, dan total asset turn over berpengaruh terhadap nilai perusahaan. Kepemilikan manajerial secara simultan mampu memperkuat pengaruh hubungan current ratio, net profit margin, debt to equity ratio, dan total asset turn over dengan nilai perusahaan.
\end{abstract}

Kata Kunci: Kinerja Keuangan, Kepemilikan Manajerial, Nilai Perusahaan

\section{PENDAHULUAN}

Perkembangan teknologi yang sangat signifikan saat ini memberikan dampak kemudahan untuk mengakses berbagai jenis informasi secara online dengan menggunakan jaringan internet. Kemajuan teknologi mempengaruhi semua disiplin ilmu termasuk dalam ilmu ekonomi, kapanpun dan dimanapun masyarakat yang ingin menjadi seorang investor dapat dengan segera mengakses profil serta laporan keuangan suatu perusahaan.

Investor adalah suatu pihak baik perorangan atau lembaga yang berasal dari dalam negeri dan luar negeri yang melakukan investasi (menanamkan modal) bersifat jangka pendek maupun jangka panjang dengan tujuan untuk memperoleh keuntungan. Investasi didefinisikan sebagai peningkatan sumber-sumber dalam jangka panjang untuk menghasilkan laba di masa yang akan datang (Mulyadi, 2005:284). Investasi adalah penundaan konsumsi sekarang untuk digunakan didalam produksi yang efisien selama periode waktu yang tertentu (Jogiyanto, 2013:5). Saham merupakan instrumen investasi yang banyak dipilih para investor karena saham mampu memberikan tingkat keuntungan yang menarik.

Menerbitkan saham merupakan salah satu pilihan perusahaan ketika memutuskan untuk pendanaan perusahaan. Investor yang ingin memutar modalnya memilih pasar modal sebagai perantara untuk membeli saham, efek-efek dan surat berharga.

Pasar modal (bursa efek) adalah sebuah pasar yang mempertemukan perusahaan sebagai pencari modal dengan investor sebagai pemilik modal, serta memperjual belikan 
surat-surat berharga berupa obligasi dan saham untuk jangka panjang yang diterbitkan oleh pemerintah maupun perusahaan swasta.

Investor tidak boleh sembarangan bertindak dalam berinvestasi karena ada banyak hal yang harus diperhatikan dan dipertimbangkan, salah satunya adalah nilai perusahaan. Harmono (2009:233) menyatakan bahwa nilai perusahaan adalah kinerja perusahaan yang dicerminkan oleh harga saham yang dibentuk oleh permintaan dan penawaran pasar modal yang merefleksikan penilaian masyarakat terhadap kinerja perusahaan. Nilai perusahaan merupakan kondisi yang telah dicapai oleh perusahaan sebagai gambaran dari kepercayaan masyarakat terhadap perusahaan setelah melalui berbagai kegiatan selama beberapa tahun, yaitu sejak perusahaan tersebut didirikan sampai dengan saat ini (Noerirawan, 2012).

Nilai perusahaan sering dikaitkan dengan harga saham, semakin tinggi harga saham maka semakin tinggi nilai perusahaannya. Nilai perusahaan yang tinggi membuat investor melirik perusahaan tersebut untuk menanamkan modalnya agar mendapatkan keuntungan yang banyak. Nilai perusahaan dapat dipengaruhi oleh beberapa alasan dan faktor-faktor, salah satunya kinerja keuangan perusahaan. Kinerja keuangan perusahaan dapat dilihat dari laporan keuangan perusahaan karena laporan keuangan mencakup berbagai macam informasi bagi investor.

Laporan keuangan adalah laporan yang menunjukkan kondisi keuangan perusahaan saat ini atau periode kedepannya (Kasmir, 2015:7). Laporan keuangan bertujuan menyediakan informasi menyangkut neraca, laba/rugi, perubahan ekuitas, arus kas, dan catatan atas laporan keuangan suatu perusahaan yang bermanfaat bagi sejumlah pemakai dalam keputusan ekonomi.

Nilai perusahaan sering dikaitkan dengan harga saham, semakin tinggi harga saham maka semakin tinggi nilai perusahaannya. Nilai perusahaan yang tinggi membuat investor melirik perusahaan tersebut untuk menanamkan modalnya agar mendapatkan keuntungan yang banyak. Nilai perusahaan dapat dipengaruhi oleh beberapa alasan dan faktor-faktor, salah satunya kinerja keuangan perusahaan. Kinerja keuangan perusahaan dapat dilihat dari laporan keuangan perusahaan karena laporan keuangan mencakup berbagai macam informasi bagi investor.

Penelitian ini merupakan gabungan dari beberapa peneliti sebelumnya serta pengembangan penelitian dari Sianturi (2015) dengan menambah variabel bebas Current Ratio (CR). Perusahaan manufaktur consumer goods yang terdaftar di Bursa Efek Indonesia dipilih sebagai objek penelitian dengan periode selama 4 tahun terhitung dari 2015-2018. Sektor consumer goods merupakan perusahaan yang menjual produk kebutuhan masyarakat seperti cosmetics, household, food, beverages, houseware, pharmaceuticals, tobacco manufacturers, dan others.

Tabel 1 Harga Saham Penutupan Sektor Consumer Goods

\begin{tabular}{lcccc}
\hline \multicolumn{1}{c}{ Bulan } & \multicolumn{4}{c}{ Tahun } \\
& 2015 & 2016 & 2017 & 2018 \\
\hline Januari & 2.256 & 2.023 & 2.344 & 2.930 \\
Februari & 2.240 & 2.348 & 2.336 & 2.838 \\
Maret & 2.311 & 2.304 & 2.432 & 2.646 \\
April & 2.336 & 2.317 & 2.438 & 2.611 \\
Mei & 2.318 & 2.345 & 2.516 & 2.363 \\
Juni & 2.226 & 2.326 & 2.557 & 2.341 \\
Juli & 2.215 & 2.454 & 2.489 & 2.452 \\
Agustus & 1.985 & 2.478 & 2.459 & 2.420 \\
September & 2.072 & 2.472 & 2.535 & 2.491
\end{tabular}




\begin{tabular}{lllll} 
Oktober & 2.129 & 2.512 & 2.516 & 2.470 \\
November & 2.072 & 2.312 & 2.613 & 2.339 \\
Desember & 2.010 & 2.261 & 2.789 & 2.608 \\
\hline
\end{tabular}

Sumber: www.idx.co.id.

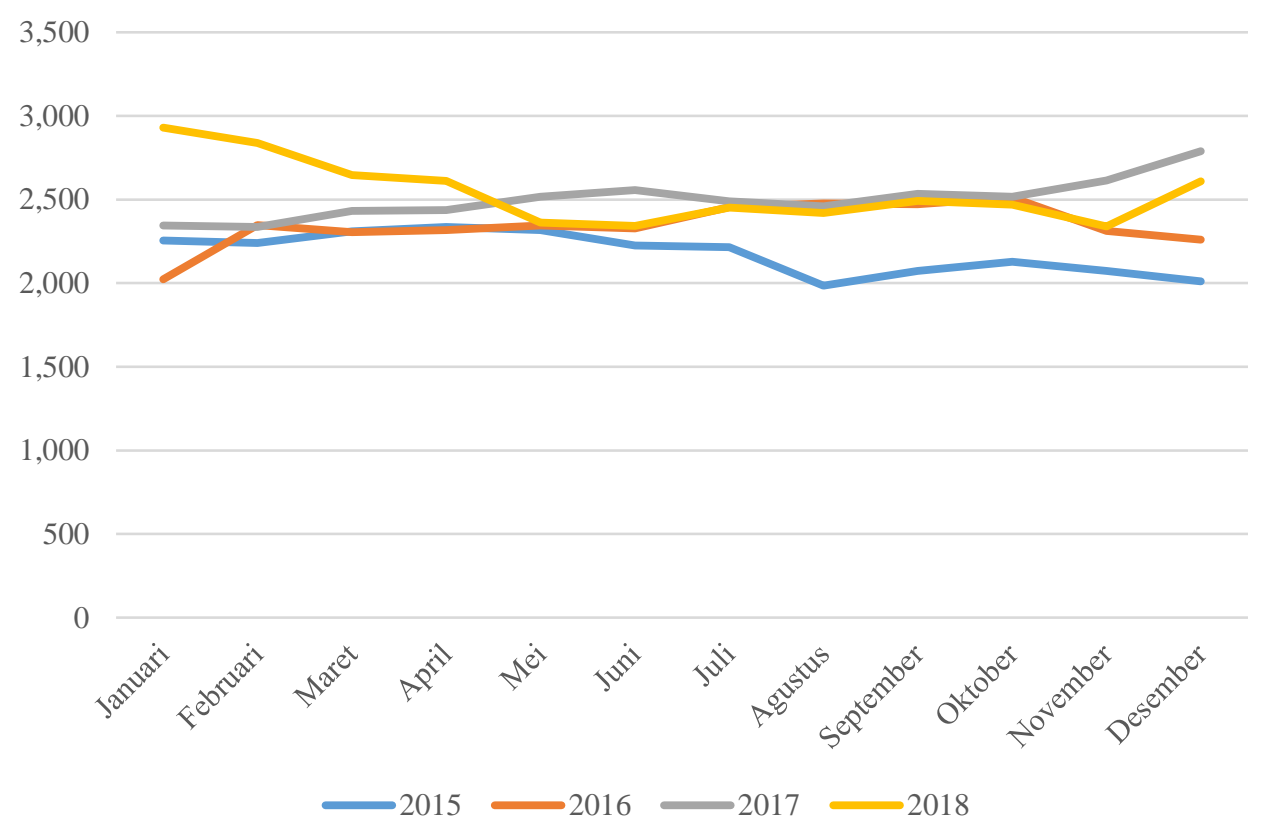

Gambar 1. Grafik Harga Saham Penutupan Sektor Consumer Goods Sumber: Data sekunder diolah, 2020.

Berdasarkan tabel 1 dan gambar 1, sektor consumer goods selama periode 2015-2018 mengalami fluktuasi harga saham. Fenomena ini mengindikasikan ketidakkonsistenan nilai perusahaan yang dapat mempengaruhi manajemen dalam mengelola keuangan perusahaan secara efektif dan efisien.

Current Ratio atau rasio lancar merupakan rasio untuk mengukur kemampuan perusahaan dalam membayar kewajiban jangka pendek atau utang yang segera jatuh tempo pada saat ditagih secara keseluruhan (Kasmir, 2015:134). Current Ratio lebih unggul karena menggunakan aktiva lancar dalam membayar kewajiban jangka pendeknya tanpa memperhitungkan persediaan dan aktiva setara kas karena hal tersebut akan membutuhkan waktu yang lama untuk diuangkan dibanding dengan aset lainnya.

Nilai perusahaan diproksikan dengan Tobin's Q. Tobin's Q dipilih sebagai variabel dependen karena menambahkan semua unsur utang dan modal saham perusahaan, tidak hanya saham biasa saja dan tidak hanya ekuitas perusahaan yang dimasukkan namun seluruh aset perusahaan (Sukamulja, 2004). Sedangkan Nilai perusahaan yang diproksikan dengan Price earning ratio (PER) mengukur harga saham per lembar perusahaan dengan earning per share (EPS) yang diperoleh pemegang saham. Earning per share mencerminkan hasil kinerja perusahaan. nilai perusahaan diproksikan dengan price book value (PBV) mengukur harga saham per lembar perusahaan dengan menggunakan ekuitas, modal yang dimiliki oleh pemegang saham selaku pemilik modal perusahaan. Tobin's lebih unggul dibandingkan PER dan PBV karena merefleksikan ekspektasi pasar sehingga relatif bebas dari kemungkinan manipulasi oleh manajemen perusahaan (www.kompasiana.com, 2017).

Kepemilikan manajerial dipilih sebagai variabel moderasi karena kepemilikan manajerial merupakan salah satu wujud dari mekanisme good corporate governance yang 
diyakini dapat meminimalisir dan mengurangi agency cost dari konflik agency antar principal dan agent terhadap sebuah perusahaan (Pratama dan Wirawati, 2016). Kepemilikan manajerial (insider ownership) adalah persentase saham yang dimiliki oleh pihak manajemen sekaligus sebagai pemegang saham. Manajemen yang mempunyai saham perusahaan memiliki kontrol terhadap perusahaan sehingga manajemen termotivasi memaksimalkan kinerjanya dalam mengelola perusahaan karena manajemen juga ikut merasakan secara langsung manfaat dari setiap keputusan yang diambilnya.

\section{TINJAUAN PUSTAKA}

\section{Nilai Perusahaan}

Nilai perusahaan merupakan pandangan investor terhadap tingkat keberhasilan perusahaan yang dikaitkan dengan harga saham, artinya harga saham merupakan fungsi dari nilai perusahaan. Harga saham yang tinggi meningkatkan kepercayaan pasar terhadap kinerja perusahaan dan prospek perusahaan di masa depan. Nilai perusahaan yang tinggi menandakan perusahaan mampu mensejahterakan pemegang sahamnya. Yulius dan Tarigan (2007:3) menyebutkan jenis-jenis nilai perusahaan berdasarkan metode perhitungan yang digunakan, yaitu nilai nominal, nilai pasar, nilai intrinsik, nilai buku, dan nilai likuidasi.

\section{Kinerja Keuangan}

Analisis kinerja keuangan merupakan proses pengkajian secara kritis terhadap review data, menghitung serta mengukur keuangan perusahaan pada suatu periode tertentu. Kinerja keuangan dapat dinilai dengan beberapa alat analisis, salah satunya adalah dengan menggunakan analisis rasio keuangan.

Rasio keuangan merupakan suatu alat dalam menganalisa dan mengukur kinerja perusahaan dengan menggunakan data keuangan perusahaan. Data-data keuangan tersebut diambil dari laporan keuangan seperti neraca, laporan laba rugi, laporan perubahan ekuitas, laporan arus kas dan catatan atas laporan keuangan. Rasio keuangan terbagi menjadi :

1. Likuiditas adalah mengukur kemampuan perusahaan dalam membayar atau melunasi kewajibannya dalam skala jangka pendek yang harus segera dipenuhi. Terdiri dari Current Ratio, Quick Ratio, Cash Ratio.

2. Profitabilitas adalah Mengukur kemampuan perusahaan dalam menghasilkan keuntungan serta memiliki peranan yang penting bagi kelangsungan hidup perusahaan karena urat nadi suatu perusahaan bergantung dari sejauh mana perusahaan bisa mendapatkan keuntungan. Rasio profitabilitas terdiri dari Gross Profit Margin, Operating Profit Margin, Net Profit Margin, Return On Assets, Return On Investment

3. Solvabilitas adalah mengukur kemampuan perusahaan melunasi semua kewajibannya, baik kewajiban jangka pendek maupun jangka panjang. Rasio solvabilitas terdiri dari Debt to Asset Ratio dan Debt to Equity Ratio.

4. Aktivitas adalah mengukur keefektifan atau efisiensi perusahaan menggunakan aktivaaktiva yang dimilikinya. Rasio aktivitas terdiri dari Accounts Receivable Turn Over, Inventory Turn Over, Fixed Assets Turn Over, dan Total Asset Turn Over.

\section{Good corporate governance}

Good corporate governance merupakan mekanisme efektivitas yang mempunyai tujuan untuk meminimalisir serta menemukan solusi terhadap konflik agency dan menciptakan nilai tambah bagi semua pihak yang berkepentingan (stakeholders) secara berkesinambungan dalam jangka panjang. Dengan pengawasan mekanisme tata kelola perusahaan yang baik 
dianggap mampu mengurangi masalah seperti perilaku dysfunctional behaviour dan kecenderungan untuk menyembunyikan informasi demi keuntungan pribadi. Pihak yang berperan dalam mewujudkan good corporate governance adalah Dewan Komisaris, Dewan Direksi, dan Komite Audit. Secara umum terdapat lima prinsip dasar dari good corporate governance yaitu Transparency (transparansi), Accountability (akuntabilitas), Responsibility (pertanggungjawaban), Independency (kemandirian), dan Fairness (kesetaraan dan kewajaran).

\section{Kerangka Pemikiran}

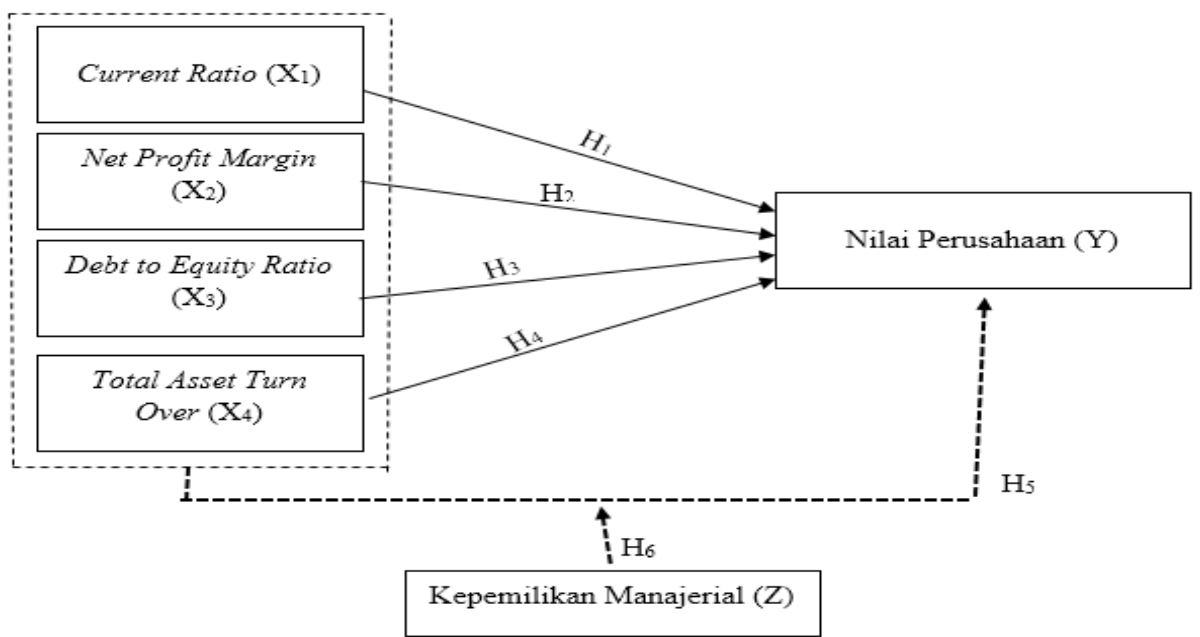

Gambar 2 Kerangka Pemikiran

Sumber: Data diolah, 2020

\section{Perumusan Hipotesis}

$\mathrm{H}_{1}$ : $\quad$ Current ratio berpengaruh positif terhadap nilai perusahaan

$\mathrm{H}_{2}$ : $\quad$ Net profit margin berpengaruh positif terhadap nilai perusahaan

$\mathrm{H}_{3}$ : $\quad$ Debt to equity ratio berpengaruh negatif terhadap nilai perusahaan

$\mathrm{H}_{4}$ : $\quad$ Total asset turn over berpengaruh positif terhadap nilai perusahaan

$\mathrm{H}_{5}$ : $\quad$ Current ratio, net profit margin, debt to equity ratio, dan total asset turn over secara simultan berpengaruh terhadap nilai perusahaan.

$\mathrm{H}_{6}$ : Kepemilikan manajerial secara simultan berpengaruh terhadap hubungan current ratio, net profit margin, debt to equity ratio, dan total asset turn over terhadap nilai perusahaan

\section{METODE PENELITIAN}

\section{Populasi dan Teknik Pengambilan Sampel}

Populasi penelitian ini adalah perusahaan manufaktur sektor consumer goods yang terdaftar di BEI tahun 2015-2018, yaitu sebanyak 68 perusahaan. Sampel penelitian ini menggunakan teknik purposive sampling. Sampel dipilih dengan kriteria sebagai berikut:

1. Perusahaan manufaktur consumer goods yang terdaftar di Bursa Efek Indonesia dan membagikan laporan keuangan secara berturut-turut selama tahun 2015-2018.

2. Data persentase kepemilikan manajerial tersedia.

Berdasarkan kriteria tersebut, diperoleh sampel sebanyak 17 perusahaan. Sampel dari penelitian ini adalah: 
Tabel 2 Sampel Penelitian

\begin{tabular}{|c|c|c|c|}
\hline No & Kode & Perusahaan & Sub Sektor \\
\hline 1. & CINT & Chitose Internasional & Houseware \\
\hline 2. & GGRM & Gudang Garam Tbk. & Tobacco Manufacturers \\
\hline 3. & INDF & Indofood Sukses & Food and Baverages \\
\hline 4. & KAEF & Kimia Farma Tbk. & Pharmaceuticals \\
\hline 5. & KINO & Kino Indonesia & Cosmetics and Household \\
\hline 6. & KLBF & Kalbe Farma & Pharmaceuticals \\
\hline 7. & MYOR & Mayora Indah Tbk. & Food and Baverages \\
\hline 8. & PYFA & Pyridam Farma Tbk. & Pharmaceuticals \\
\hline 9. & SIDO & $\begin{array}{l}\text { Industri Jamu dan Farmasi Sido } \\
\text { Muncul Tbk. }\end{array}$ & Pharmaceuticals \\
\hline 10. & SKBM & Sekar Bumi Tbk. & Food and Baverages \\
\hline 11. & SKLT & Sekar Laut Tbk. & Food and Baverages \\
\hline 12. & STTP & Siantar Top Tbk. & Food and Baverages \\
\hline 13. & TCID & Mandom Indonesia & Cosmetics and Household \\
\hline 14. & TSPC & Tempo Scan Pacific Tbk. & Pharmaceuticals \\
\hline 15. & ULTJ & Ultra Jaya Milk industry & Food and Baverages \\
\hline 16. & UNVR & Unilever Indonesia & Cosmetics and Household \\
\hline 17. & WIIM & Wismilak Inti Makmur & Tobacco Manufacturers \\
\hline
\end{tabular}

Sumber: $\underline{w w w . i d x . c o . i d}$.

Teknik Analisa Data

\section{Analisis Regresi Berganda}

Analisis regresi berganda digunakan untuk mengetahui pengaruh variabel independen terhadap variabel dependen (Ghozali, 2016). Dengan persamaan sebagai berikut:

$$
\mathrm{Y}=-\mathrm{a}+\beta_{1} \mathrm{X}_{1}+\beta_{2} \mathrm{X}_{2}+\beta_{3} \mathrm{X}_{3}+\beta_{4} \mathrm{X}_{4}+\mathrm{e} \ldots
$$

Keterangan :

$\mathrm{Y}=$ Nilai Perusahaan

$$
\mathrm{X}_{2} \quad=\text { Net Profit Margin }
$$

a $\quad=$ Konstanta

$\beta_{1-} \beta_{9}=$ Koefisien Regresi

$\mathrm{X}_{3} \quad=$ Debt to Equity Ratio

$\mathrm{X}_{1}=$ Current Ratio

$\mathrm{X}_{4} \quad=$ Total Assets Turn Over

$\mathrm{e} \quad=$ Standard error

\section{Analisis regresi moderasi}

Analisis regresi moderasi atau Moderated Regression Analysis (MRA)_digunakan untuk mengetahui pengaruh variabel independen terhadap variabel dependen dan kemampuan variabel moderasi dalam memoderasi pengaruh variabel independen terhadap variabel dependen. Dengan persamaan sebagai berikut: 
$Y=-a+\beta_{1} X_{1}+\beta_{2} X_{2}+\beta_{3} X_{3}+\beta_{4} X_{4}+\beta_{5} Z-\beta_{6} X_{1} * Z+\beta_{7} X_{2} * Z+\beta_{8} X_{3} * Z-\beta_{9} X_{4} * Z+e$

Keterangan :

$\mathrm{Y}=$ Nilai Perusahaan $\quad \mathrm{X}_{3}=$ Debt to Equity Ratio

a $\quad=$ Konstanta $\quad X_{4} \quad=$ Total Assets Turn Over

$\beta_{1-} \beta_{9}=$ Koefisien Regresi $\quad Z \quad=$ Kepemilikan Manajerial

$\mathrm{X}_{1}=$ Current Ratio e = Standard error

$\mathrm{X}_{2}=$ Net Profit Margin

\section{Uji Hipotesis}

a. Uji T

Uji T bertujuan untuk menguji pengaruh variabel independen secara individual terhadap variabel dependen.

b. Uji F

Uji F bertujuan untuk menguji pengaruh variabel independen secara bersama-sama atau gabungan terhadap variabel dependen.

\section{HASIL PENELITIAN DAN PEMBAHASAN}

\section{Hasil Uji Analisis Regresi Berganda}

Adapun hasil pengujian resgresi berganda dapat dilihat tabel berikut:

Tabel 2 Hasil Uji Analisis Regresi Berganda

Coefficients $^{\mathrm{a}}$

\begin{tabular}{|c|c|c|c|c|c|c|}
\hline \multirow{2}{*}{\multicolumn{2}{|c|}{ Model }} & \multicolumn{2}{|c|}{ Unstandardized Coefficients } & \multirow{2}{*}{$\begin{array}{l}\text { Standardized } \\
\text { Coefficients } \\
\text { Beta }\end{array}$} & \multirow[b]{2}{*}{$\mathrm{t}$} & \multirow[b]{2}{*}{ Sig. } \\
\hline & & B & Std. Error & & & \\
\hline 1 & (Constant) & -4.326 & 1.362 & & -3.175 & .002 \\
\hline & CR (X1) & .117 & .219 & .075 & .533 & .596 \\
\hline & NPM (X2) & .515 & .065 & .826 & 7.873 & .000 \\
\hline & DER (X3) & 1.807 & .723 & .347 & 2.499 & .016 \\
\hline & TATO (X4) & 1.817 & .809 & .215 & 2.247 & .029 \\
\hline
\end{tabular}

a. Dependent Variable: NILAI PERUSAHAAN (Y)

Sumber: Output SPSS. 2021

Berdasarkan hasil analisis regresi berganda seperti pada tabel 2, diperoleh persamaan regresi sebagai berikut:

Nilai Perusahaan $=\quad-4,326+0,117 \mathrm{CR}+0,515 \mathrm{NPM}+1,807 \mathrm{DER}+1,817 \mathrm{TATO}+\mathrm{e}$

Berdasarkan persamaan regresi tersebut, dapat dijelaskan bahwa:

1. Konstanta $(\alpha)$ sebesar $-4,326$. Hal ini menunjukkan bahwa jika besarnya seluruh variabel independen adalah 0, maka besarnya nilai perusahaan adalah sebesar $-4,326$.

2. Koefisien regresi CR diperoleh nilai positif 0,117 . Hal ini dapat diartikan jika CR bertambah atau naik sebesar 1 akan menyebabkan peningkatan nilai perusahaan sebesar 0,117 . 
3. Koefisien regresi NPM diperoleh nilai positif 0,515. Hal ini dapat diartikan jika NPM bertambah atau naik sebesar 1 akan menyebabkan peningkatan nilai perusahaan sebesar 0,515 .

4. Koefisien regresi DER diperoleh nilai positif 1,807 . Hal ini dapat diartikan jika DER bertambah atau naik sebesar 1 akan menyebabkan peningkatan nilai perusahaan sebesar 1,807 .

5. Koefisien regresi TATO diperoleh nilai positif 1,817 . Hal ini dapat diartikan jika TATO bertambah atau naik sebesar 1 akan menyebabkan peningkatan nilai perusahaan sebesar 1,817 .

\section{Hasil pengujian Moderated Regression Analysis (MRA)}

Adapun hasil pengujian Moderated Regression Analysis (MRA) dapat dilihat pada tabel sebagai sebagai berikut:

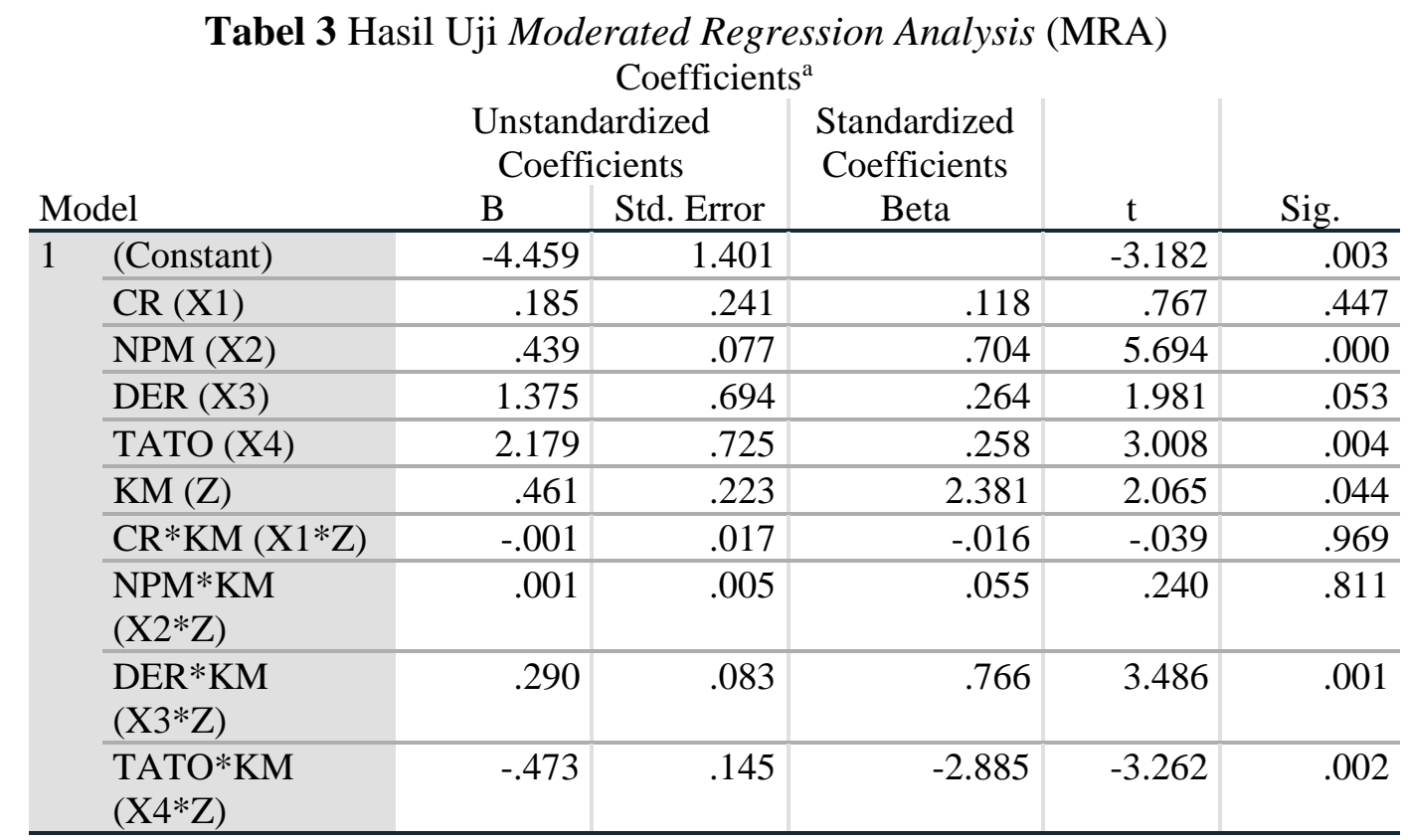

a. Dependent Variable: NILAI PERUSAHAAN (Y)

Sumber: Output SPSS. 2021

Berdasarkan hasil pengujian Moderated Regression Analysis (MRA) diperoleh persamaan regresi sebagai berikut:

NILAI PERUSAHAAN $=-4,459+0,185 \mathrm{CR}+0,439 \mathrm{NPM}+1,375 \mathrm{DER}+2,179$ TATO + $0,461 \mathrm{KM}-0,001 \mathrm{CR} * \mathrm{KM}+0,001 \mathrm{NPM} * \mathrm{KM}+0,290$ DER*KM - 0,473 TATO*KM + e

Berdasarkan persamaan regresi tersebut, dapat dijelaskan bahwa:

1. Konstanta $(\alpha)$ sebesar $-4,459$. Hal ini menunjukkan bahwa jika besarnya variabel independen, variabel dependen, dan interaksi variabel independen dengan moderasi 0 , maka besar nilai perusahaan adalah sebesar $-4,459$.

2. Koefisien regresi CR memperoleh nilai positif sebesar 0,185. Hal ini dapat diartikan jika CR bertambah atau naik sebesar 1 akan menyebabkan penurunan nilai perusahaan sebesar 0,185 . 
3. Koefisien regresi NPM memperoleh nilai positif sebesar 0,439. Hal ini dapat diartikan jika NPM bertambah atau naik sebesar 1 akan menyebabkan peningkatan nilai perusahaan sebesar 0,439 .

4. Koefisien regresi DER memperoleh nilai positif sebesar 1,375 . Hal ini dapat diartikan jika DER bertambah atau naik sebesar 1 akan menyebabkan penurunan nilai perusahaan sebesar 1,375.

5. Koefisien regresi TATO memperoleh nilai positif sebesar 2,179. Hal ini dapat diartikan jika TATO bertambah atau naik sebesar 1 akan menyebabkan penurunan nilai perusahaan sebesar 2,179.

6. Koefisien regresi KM memperoleh nilai positif sebesar 0,461. Hal ini dapat diartikan jika KM bertambah atau naik 1 akan menyebabkan penurunan nilai perusahaan sebesar 0,461 .

7. Koefisien regresi interaksi antara CR dengan KM diperoleh nilai negatif sebesar $-0,001$. Hal ini dapat diartikan jika interaksi antara CR dengan KM bertambah atau naik sebesar 1 akan menyebabkan peningkatan nilai perusahaan sebesar $-0,001$.

8. Koefisien regresi interaksi antara NPM dengan KM diperoleh nilai positif sebesar 0,001 . Hal ini dapat diartikan jika interaksi antara NPM dengan KM bertambah atau naik sebesar 1 akan menyebabkan penurunan nilai perusahaan sebesar 0,001.

9. Koefisien regresi interaksi antara DER dengan KM diperoleh nilai positif sebesar 0,290. Hal ini dapat diartikan jika interaksi antara DER dengan KM bertambah atau naik sebesar 1 akan menyebabkan peningkatan nilai perusahaan sebesar 0,290.

10. Koefisien regresi interaksi antara TATO dengan KM diperoleh nilai negatif sebesar 0,473. Hal ini dapat diartikan jika interaksi antara TATO dengan KM bertambah atau naik sebesar 1 akan menyebabkan peningkatan nilai perusahaan sebesar -0,473.

\section{Hasil Uji T (Parsial)}

Adapun hasil uji $\mathrm{T}$ dapat dilihat pada tabel sebagai berikut:

\begin{tabular}{|c|c|c|c|c|c|c|}
\hline \multicolumn{7}{|c|}{$\begin{array}{c}\text { Tabel } 4 \text { Hasil Uji T (Parsial) } \\
\text { Coefficients }^{\mathrm{a}}\end{array}$} \\
\hline \multirow{2}{*}{\multicolumn{2}{|c|}{ Model }} & \multicolumn{2}{|c|}{$\begin{array}{l}\text { Unstandardized } \\
\text { Coefficients }\end{array}$} & \multirow{2}{*}{$\begin{array}{c}\text { Standardized } \\
\text { Coefficients } \\
\text { Beta }\end{array}$} & \multirow[b]{2}{*}{$\mathrm{t}$} & \multirow[b]{2}{*}{ Sig. } \\
\hline & & $\mathrm{B}$ & Std. Error & & & \\
\hline 1 & (Constant) & -4.326 & 1.362 & & -3.175 & .002 \\
\hline & CR (X1) & .117 & .219 & .075 & .533 & .596 \\
\hline & NPM (X2) & .515 & .065 & .826 & 7.873 & .000 \\
\hline & DER (X3) & 1.807 & .723 & .347 & 2.499 & .016 \\
\hline & TATO $(\mathrm{X} 4)$ & 1.817 & .809 & .215 & 2.247 & .029 \\
\hline
\end{tabular}

a. Dependent Variable: NILAI PERUSAHAAN (Y)

Sumber: Output SPSS, 2021.

Dari Tabel 4, dapat dilihat bahwa CR memperoleh nilai $\mathrm{T}_{\text {hitung }}$ kearah positif sebesar 0,533 lebih kecil dari nilai $T_{\text {tabel }}$ yaitu 1,674 dan mempunyai nilai probabilitas signifikan sebesar 0,596 lebih besar dari 0,05, hal ini menunjukkan bahwa CR tidak berpengaruh terhadap nilai perusahaan. Variabel NPM memperoleh nilai $T_{\text {hitung }}$ kearah positif sebesar 7,873 lebih besar dari nilai $\mathrm{T}_{\text {tabel }}$ yaitu 1,674 dan mempunyai nilai probabilitas signifikan sebesar 0,000 lebih kecil dari 0,05 , hal ini menunjukkan bahwa NPM berpengaruh positif terhadap nilai perusahaan. Variabel DER memperoleh nilai $\mathrm{T}_{\text {hitung }}$ kearah positif sebesar 2,499 lebih besar 
dari nilai $\mathrm{T}_{\text {tabel }}$ yaitu 1,674 dan mempunyai nilai probabilitas signifikan sebesar 0,016 lebih kecil dari 0,05, hal ini menunjukkan bahwa DER berpengaruh positif terhadap nilai

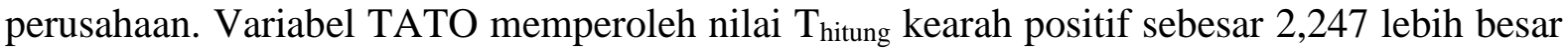
dari nilai $T_{\text {tabel }}$ yaitu 1,674 dan mempunyai nilai probabilitas signifikan sebesar 0,029 lebih kecil dari 0,05 , hal ini menunjukkan bahwa TATO berpengaruh positif terhadap nilai perusahaan.

\section{Hasil Uji F}

Adapun untuk hasil uji F dapat dilihat pada Tabel 5 dan Tabel 6 sebagai berikut:

\begin{tabular}{|c|c|c|c|c|c|c|}
\hline \multicolumn{7}{|c|}{$\begin{array}{c}\text { Tabel } 5 \text { Hasil Uji F (Simultan) } \\
\text { ANOVA }^{\text {a }}\end{array}$} \\
\hline \multicolumn{2}{|c|}{ Model } & $\begin{array}{l}\text { Sum of } \\
\text { Squares }\end{array}$ & $\mathrm{df}$ & Mean Square & $\mathrm{F}$ & Sig. \\
\hline 1 & Regression & 144.296 & 4 & 36.074 & 17.359 & $.000^{\mathrm{b}}$ \\
\hline & Residual & 110.141 & 53 & 2.078 & & \\
\hline & Total & 254.437 & 57 & & & \\
\hline
\end{tabular}

a. Dependent Variable: NILAI PERUSAHAAN (Y)

b. Predictors: (Constant), TATO (X4), CR (X1), NPM (X2), DER (X3)

Sumber: Output SPSS, 2021.

Dari Tabel 5, dapat dilihat CR, NPM, DER, dan TATO secara simultan mempunyai nilai probabilitas signifikan sebesar 0,000 lebih kecil dari 0,05 dan mempunyai nilai $F_{\text {hitung positif }}$ sebesar 17,359 lebih besar dari nilai $F_{\text {tabel }}$ yaitu 2,55. Hal ini menunjukkan bahwa model yang digunakan dapat dipakai untuk menjelaskan variasi variabel independen terhadap variabel dependen. Sehingga dapat disimpulkan bahwa CR, NPM, DER, dan TATO secara simultan berpengaruh positif terhadap nilai perusahaan.

Tabel 6 Hasil Uji F (Simultan) dengan Variabel Moderasi

\begin{tabular}{|c|c|c|c|c|c|c|}
\hline & & & $\mathrm{JOVA}^{\mathrm{a}}$ & & & \\
\hline & & $\begin{array}{l}\text { Sum of } \\
\text { Squares }\end{array}$ & $\mathrm{df}$ & Mean Square & $\mathrm{F}$ & Sig. \\
\hline 1 & Regression & 186.038 & 9 & 20.671 & 14.506 & $.000^{\mathrm{b}}$ \\
\hline & Residual & 68.400 & 48 & 1.425 & & \\
\hline & Total & 254.437 & 57 & & & \\
\hline
\end{tabular}

a. Dependent Variable: NILAI PERUSAHAAN (Y)

b. Predictors: (Constant), TATO*KM (X4*Z), NPM (X2), TATO (X4), DER

(X3), CR (X1), DER*KM (X3*Z), NPM*KM (X2*Z), CR*KM (X1*Z), KM (Z)

Sumber: Output SPSS, 2021.

Dari Tabel 6, dapat dilihat secara simultan nilai probabilitas signifikannya sebesar 0,000 lebih kecil dari 0,05 dan mempunyai nilai $F_{\text {hitung }}$ ke arah positif sebesar 14,506 lebih besar dari nilai $F_{\text {tabel }}$ yaitu 2,08. Hal ini menunjukkan bahwa model yang digunakan dapat dipakai untuk menjelaskan variasi variabel moderasi dalam memoderasi hubungan variabel independen dengan variabel dependen. Sehingga dapat disimpulkan bahwa KM (Kepemilikan Manajerial) sebagai variabel moderasi secara simultan berpengaruh positif terhadap hubungan CR, NPM, DER,dan TATO dengan nilai perusahaan. 


\section{Pengaruh Current Ratio terhadap Nilai Perusahaan}

Berdasarkan hasil uji $\mathrm{T}$ pada Tabel 4 , menunjukkan bahwa $\mathrm{T}_{\text {hitung }}<\mathrm{T}_{\text {tabel }}(0,533<1,674)$ dengan tingkat signifikansi 0,596 lebih besar dari 0,05 sehingga $\mathrm{H}_{1}$ yang menyatakan current ratio berpengaruh terhadap nilai perusahaan ditolak. Koefisien regresi yang bernilai positif menandakan hubungan current ratio berpengaruh positif terhadap nilai perusahaan yang berarti semakin tinggi nilai current ratio maka nilai perusahaan semakin meningkat.

\section{Pengaruh Net Profit Margin terhadap Nilai Perusahaan}

Berdasarkan hasil uji $\mathrm{T}$ pada Tabel 4 , menunjukkan bahwa $\mathrm{T}_{\text {hitung }}>\mathrm{T}_{\text {tabel }}(7,873>1,674)$ dengan tingkat signifikansi 0,000 lebih kecil dari 0,05 sehingga $\mathrm{H}_{2}$ yang menyatakan net profit margin berpengaruh terhadap nilai perusahaan diterima. Koefisien regresi yang bernilai positif menandakan hubungan net profit margin berpengaruh positif terhadap nilai perusahaan yang berarti semakin tinggi nilai net profit margin maka nilai perusahaan semakin meningkat.

\section{Pengaruh Debt to Equity Ratio terhadap Nilai Perusahaan}

Berdasarkan hasil uji $\mathrm{T}$ pada Tabel 4, menunjukkan bahwa $\mathrm{T}_{\text {hitung }}>\mathrm{T}_{\text {tabel }}(2,499>1,674)$ dengan tingkat signifikansi 0,016 lebih kecil dari 0,05 sehingga $\mathrm{H}_{3}$ yang menyatakan debt to equity ratio berpengaruh terhadap nilai perusahaan diterima. Koefisien regresi yang bernilai positif menandakan hubungan debt to equity ratio berpengaruh positif terhadap nilai perusahaan yang berarti semakin tinggi nilai debt to equity ratio maka nilai perusahaan semakin meningkat.

\section{Pengaruh Total Asset Turn Over terhadap Nilai Perusahaan}

Berdasarkan hasil uji $\mathrm{T}$ pada Tabel 4, menunjukkan bahwa $\mathrm{T}_{\text {hitung }}>\mathrm{T}_{\text {tabel }}(2,247>1,674)$ dengan tingkat signifikansi 0,029 lebih kecil dari 0,05 sehingga $\mathrm{H}_{4}$ yang menyatakan total asset turn over berpengaruh terhadap nilai perusahaan diterima. Koefisien regresi yang bernilai positif menandakan hubungan total asset turn over berpengaruh positif terhadap nilai perusahaan yang berarti semakin tinggi nilai total asset turn over maka nilai perusahaan semakin meningkat.

\section{Pengaruh Current Ratio, Net Profit Margin, Debt to Equity Ratio, dan Total Asset} Turn Over secara simultan terhadap Nilai Perusahaan

Berdasarkan hasil uji $\mathrm{F}$ pada Tabel 5, menunjukkan bahwa $F_{\text {hitung }}>F_{\text {tabel }}(17,359>2,55)$ dengan tingkat signifikansi 0,000 lebih kecil dari 0,05 sehingga current ratio, net profit margin, debt to equity ratio, dan total asset turn over secara simultan berpengaruh terhadap nilai perusahaan.

Pengaruh Kepemilikan Manajerial secara simultan terhadap hubungan Current Ratio, Net Profit Margin, Debt to Equity Ratio, dan Total Asset Turn Over dengan Nilai Perusahaan

Berdasarkan hasil uji $\mathrm{F}$ pada Tabel 4.11, menunjukkan bahwa $F_{\text {hitung }}>F_{\text {tabel }}(14,506>2,08)$ dengan tingkat signifikansi 0,000 lebih kecil dari 0,05 sehingga variabel moderasi kepemilikan manajerial secara simultan berpengaruh terhadap hubungan current ratio, net profit margin, debt to equity ratio, dan total asset turn over dengan nilai perusahaan. Selanjutnya, diketahui nilai koefisien determinasi (Adjusted $R$ Square) sebelum dimasukkan variabel moderasi adalah sebesar 0,534 atau 53,4\% kemudian setelah dimasukkan variabel moderasi, nilai koefisien determinasi (Adjusted $R$ Square) meningkat menjadi 0,681 atau 
68,1\%. Hal tersebut menunjukkan bahwa dengan adanya kepemilikan manajerial sebagai variabel moderasi, secara simultan mampu memperkuat hubungan variabel independen dengan variabel dependen.

\section{KESIMPULAN DAN SARAN}

\section{Kesimpulan}

1. Berdasarkan hasil penelitian, didapatkan bukti empiris bahwa secara parsial Current Ratio tidak berpengaruh terhadap nilai perusahaan pada perusahaan Consumer Goods tahun 2015-2018.

2. Berdasarkan hasil penelitian, didapatkan bukti empiris bahwa secara parsial Net Profit Margin berpengaruh positif terhadap nilai perusahaan pada perusahaan Consumer Goods tahun 2015-2018.

3. Berdasarkan hasil penelitian, didapatkan bukti empiris bahwa secara parsial Debt to Equity Ratio berpengaruh positif terhadap nilai perusahaan pada perusahaan Consumer Goods tahun 2015-2018.

4. Berdasarkan hasil penelitian, didapatkan bukti empiris bahwa secara parsial Total Asset Turn Over berpengaruh positif terhadap nilai perusahaan pada perusahaan Consumer Goods tahun 2015-2018.

5. Berdasarkan hasil penelitian, didapatkan bukti empiris bahwa secara simultan Current Ratio, Net Profit Margin, Debt to Equity Ratio, dan Total Asset Turn Over berpengaruh terhadap nilai perusahaan pada perusahaan Consumer Goods tahun 2015-2018.

6. Berdasarkan hasil penelitian, didapatkan bukti empiris bahwa secara simultan Kepemilikan Manajerial mampu memperkuat pengaruh hubungan Current Ratio, Net Profit Margin, Debt to Equity Ratio, dan Total Asset Turn Over dengan nilai perusahaan pada perusahaan Consumer Goods tahun 2015-2018.

\section{Saran}

1. Bagi investor yang ingin berinvestasi saham pada perusahaan consumer goods, sebaiknya melihat terlebih dahulu kondisi keuangan perusahaan serta menilai faktorfaktor yang akan mempengaruhi pergerakan harga saham seperti net profit margin, debt to equity ratio, dan total asset turn over karena ketiga variabel tersebut memiliki pengaruh signifikan terhadap nilai perusahaan pada penelitian ini.

2. Bagi peneliti selanjutnya diharapkan mengganti dan menambah variabel independen yang dapat mempengaruhi nilai perusahaan seperti ukuran perusahaan, pertumbuhan aset perusahaan, dan umur perusahaan. Peneliti selanjutnya dapat memperpanjang periode serta menambah populasi penelitian agar memperoleh hasil penelitian yang lebih baik dan akurat.

\section{DAFTAR PUSTAKA}

Anggitasari, N. 2012. Pengaruh Kinerja Keuangan terhadap Nilai Perusahaan dengan pengungkapan Corporate Social Responsibility dan Struktur Good Corporate Governance sebagai Variabel Pemoderasi. Skripsi. Semarang: Universitas Diponegoro. (http://eprints.undip.ac.id/36171/1/ANGGITASARI.pdf, diakses 26 September 2019)

Asmoro, S.R., Fidiana. 2015. Struktur Pendanaan dan Pengaruhnya Terhadap Nilai Perusahaan dengan Kepemilikan Manajerial Sebagai Pemoderasi. Jurnal Ilmu \& Riset Akuntansi Vol.4 No.1. 
(http://jurnalmahasiswa.stiesia.ac.id/index.php/jira/article/view/406/414, diakses 16 Mei 2020)

Astutik, Dwi. 2017. Pengaruh Aktivitas Rasio Keuangan Terhadap Nilai Perusahaan (Studi Pada Industri Manufaktur). Jurnal STIE Semarang. Vol.9 No.1. Februari. Hal 32-49. (http://jurnal3.stiesemarang.ac.id/index.php/jurnal/article/view/28/20, diakses 12 Mei 2020)

Atmaja, I.G.N.Y.D., Astika I.B.P. 2018. Pengaruh Profitabilitas, Leverage, dan Modal Kerja pada Nilai Perusahaan dengan CSR sebagai Variabel Intervening. E-Jurnal Akuntansi Universitas Udayana. ISSN 2302-8556. Vol.24 No.1. Juni. Hal 1-29.

(https://ojs.unud.ac.id/index.php/akuntansi/article/download/33717/24335, diakses 12 November 2019)

Budianto, W., Payamta. 2014. Pengaruh Kepemilikan Manajerial Terhadap Nilai Perusahaan dengan Kebijakan Dividen Sebagai Variabel Moderasi. Jurnal Akuntansi dan Pendidikan. Vol.3 No.1. April.

(http://e-journal.unipma.ac.id/index.php/assets/article/view/1207, diakses 16 Mei 2020)

Devi, P.N.C., Supadmi N.L. 2018. Pengaruh Agresivitas Pajak pada Nilai Perusahaan dengan Ukuran Perusahaan Sebagai Pemoderasi. E-Jurnal Akuntansi Universitas Udayana. ISSN 2302-8556. Vol.22 No.3.Maret. Hal 2257-2283.

(https://ojs.unud.ac.id/index.php/akuntansi/article/download/37045/22971, diakses 10 November 2019)

Firnanda, Taurisina., Hening Widi Oetomo. 2016. Analisis Likuiditas, Profitabilitas, Solvabilitas, dan Perputaran Persediaan Terhadap Nilai Perusahaan. Jurnal Ilmu dan Riset Manajemen : Volume 5, Nomor 2.

(http://jurnalmahasiswa.stiesia.ac.id/index.php/jirm/article/view/437/445)

Ghozali, Imam. 2016. Aplikasi Analisis Multivariete dengan Program IBM SPSS 23, edisi 8. Semarang: Badan Penerbit Undip.

Gunawan, Leonardy. 2017. Pengaruh Net Profit Margin dan Total Asset Turn over terhadap Nilai Perusahaan pada Sektor Industri Barang konsumsi Yang Terdaftar Dibursa Efek Indonesia. STIE Widya Dharma Pontianak.

(http://journal.widyadharma.ac.id/index.php/mabis/article/download/528/547 diakses 8 Desember 2020)

Harmono. 2009. Manajemen Keuangan Berbasis Balanced Scorecard (Pendekatan Teori, Kasus, dan Riset Bisnis).

Hasania, Z., Murni S., Mandagie Y. 2016. Pengaruh Current Ratio, Ukuran Perusahaan, Struktur modal, dan ROE Terhadap Nilai Perusahaan Farmasi yang Terdaftar di Bursa Efek Indonesia Periode 2011-2014. Jurnal Berkala Ilmiah Efisiensi. Vol. 16 No.3. Hal 133-144.

(http://ejournal.unsrat.ac.id/index.php/jbie/article/view/13107/12692, diakses 24 Desember 2019)

https://ilmumanajemenindustri.com/pengertian-net-profit-margin-marjin-laba-bersih-rumus$\underline{\mathrm{npm} /}$

https://www.spssindonesia.com/2016/08/cara-melakukan-uji-f-simultan-dalam.html https://www.kompasiana.com/betrikaoktaresa/594d532beec6ec2c437c0282/mengukurkinerja-perusahaan-dengan-tobin-sq\#: :text=Melalui\%20penjelasan\%20dan\%20contoh\%20di,kemungkinan\%20manipula si\%20oleh\%20manajemen\%20perusahaan 
Irawati, Erni. 2016. Faktor Determinan Nilai Perusahaan pada Perusahaan Manufaktur yang Terdaftar di Bursa Efek Indonesia. Skripsi. Yogyakarta: Universitas Negeri Yogyakarta.

(http://eprints.uny.ac.id/41482/1/ErniIrawati_12808141014.pdf, diakses 10 Mei 2020)

Kasmir, 2015. Analisis Laporan Keuangan. Edisi 8. Jakarta: PT Rajagrafindo Persada.

Kusumawati, R., Rosady I. 2018. Pengaruh Struktur Modal dan Profitabilitas Terhadap Nilai Perusahaan dengan Kepemilikan Manajerial sebagai Variabel Moderasi. Jurnal Manajemen Bisnis. Vol.9 No. 2. Hal 147-160.

(http://journal.umy.ac.id/index.php/mb/article/view/5567/4043, diakses 29 Desember $\underline{2019)}$

Lestari, Mellinda. 2019. Faktor-faktor yang Memengaruhi Nilai Perusahaan pada Perusahaan Real Estate dan Property yang Terdaftar di Bursa Efek Indonesia. Skripsi. Banjarmasin: STIE Indonesia Banjarmasin.

Muliani, L.E., Yuniarta G.A., Sinarwati K. 2014. Pengaruh Kinerja Keuangan Terhadap Nilai Perusahaan dengan Pengungkapan Corporate Social Responcibility dan Good Corporate Governance Sebagai Variabel Pemoderasi (Studi Kasus Di Bursa Efek Indonesia Periode 2010-2012). e-Journal S1 Ak Universitas Pendidikan Ganesha. Vol.2 No.1.

(https://ejournal.undiksha.ac.id/index.php/s1ak/article/download/3423/2784, diakses 24 Desember 2019)

Mulyadi. 2005. Akuntansi Manajemen.

Nafisah, Nila Izatun. 2018. Pengaruh Return On Assets (Roa), Debt to Equity Ratio (Der), Current Ratio (Cr), Return On Equity (Roe), Price Earning Ratio (Per), Total Assets Turnover (Tato), Dan Earning Per Share (Eps) Terhadap Nilai Perusahaan Manufaktur Yang Terdaftar Di Bei Tahun 2014-2015. Jurnal Riset Mahasiswa Akuntansi. JRMA, Vol.6 No.2.

(http://ejournal.unikama.ac.id/index.php/jrma/article/view/4217/2496 diakses 8 Desember 2020)

Noorhidayat. 2019. Faktor-faktor yang Memengaruhi Nilai Perusahaan pada Perusahaan Manufaktur Sub Sektor Logam yang Listing di Bursa Efek Indonesia. Skripsi. Banjarmasin: STIE Indonesia Banjarmasin.

Noviani, A.F., Atahau A.D.R., Robiyanto R. 2019. Struktur modal, profitabilitas, dan nilai perusahaan: Efek moderasi Good Corporate Governance. Jurnal Ekonomi dan Bisnis. Vol. 22 No.2. Oktober. Hal 391-415.

(https://ejournal.uksw.edu/jeb/article/view/2601/1293, diakses 23 Oktober 2019)

Novianti, R.W., Mardani R.M., Wahono B. 2018. Pengaruh Curent Ratio, Total Asset Turn Over, Net Profit Margin, dan Debt to Equity Ratio Terhadap Nilai Perusahaan. EJurnal Riset Manajemen. Hal 97-110.

(http://riset.unisma.ac.id/index.php/jrm/article/view/4100/3570, diakses 26 September $\underline{\text { 2019) }}$

Phitaloka, N.G. 2018. Pengaruh Struktur Modal dan Profitabilitas Terhadap Nilai Perusahaan dengan Kepemilikan Manajerial Sebagai Pemoderasi pada Sektor Properti dan Real Estate yang Terdaftar di BEI. Skripsi. Surabaya: STIE PERBANAS. (http://eprints.perbanas.ac.id/3758/2/BAB\%20V.pdf, diakses 16 Mei 2020)

Pratama, I.G.G.W., Wirawati N.G.P. 2016. Pengaruh Struktur Modal dan Profitabilitas terhadap Nilai Perusahaan dengan Kepemilikan Manajerial sebagai Pemoderasi. E- 
Jurnal Akuntansi Universitas Udayana. ISSN 2302-8556. Vol.15 No.3. Juni. Hal 17961825.

(https://ojs.unud.ac.id/index.php/Akuntansi/article/download/15887/13947, diakses 7 November 2019)

Rinnaya, I.Y., Andini R., Oemar A. 2016. Pengaruh Profitabilitas, Rasio Aktivitas, Keputusan Investasi terhadap Nilai Perusahaan (Studi Empiris Pada Perusahaan Manufaktur yang Terdaftar di BEI Tahun 2010-2014). Jurnal of Accounting. Vol.2 No.2

(http://jurnal.unpand.ac.id/index.php/AKS/article/view/438/425, diakses 27 Desember $\underline{\text { 2019) }}$

Rofelawaty B., Artinah B., dan Kadir A. 2018. Teori Akuntansi. Edisi kedua. Banjarbaru: Penerbit Scripta Cendekia.

Rompas, Gisella Prisilia. 2013. Likuiditas, Solvabilitas dan Rentabilitas terhadap Nilai Perusahaan BUMN yang Terdaftar dibursa Efek Indonesia. Jurnal EMBA. Universitas Sam Ratulangi. Vol.1 No.3. September. Hal 252-262.

(https://ejournal.unsrat.ac.id/index.php/emba/article/view/2014/160, diakses 24 November 2019)

Sari, Putu Ratih dan Anak A.N.B.D. 2019. Pengaruh Current Ratio Dan Debt to Equity RatioTerhadapProfitabilitas Dengan Intellectual Capital Sebagai Pemoderasi. E-Jurnal Akuntansi Universitas Udayana. Vol.26. Februari. Hal 851-880. (https://pdfs.semanticscholar.org/94cf/f86e18b3b2798cd5182c5e126d73bfd90c14.pdf, diakses 12 Mei 2020)

Sarinah., Hariyanto D., Safitri H. 2019. Pengaruh Likuiditas, Solvabilitas, Aktivitas dan Propitabilitas Terhadap Nilai Perusahaan pada Sektor Pertambangan. Jurnal produktivitas 6. Hal 24-33.

(http://p3i.unmuhpnk.ac.id/index.php/jp/article/view/1473/1120, diakses 29 Desember $\underline{2019)}$

Sianturi, M Wanti Ernita. 2015. Pengaruh Kinerja Keuangan Terhadap Nilai Perusahaan Manufaktur Sektor Industri Barang Konsumsi Di Bei. eJournal Ilmu Administrasi Bisnis, 3 (2):282-296. (https://ejournal.hi.fisip-unmul.ac.id/site/wp-content/uploads/2015/05/eJournal\%20(0506-15-05-26-39).pdf diakses 8 Desember 2020)

Sijabat, Frengky David dan Anak A.G.S. 2018. Pengaruh DPR, DER, ROA dan ROE Terhadap Price Earning Ratio pada Perusahaan Manufaktur. E-Jurnal Unud. Vol.7 No.7. Hal 3681-3708.

(https://media.neliti.com/media/publications/254723-pengaruh-dpr-der-roa-dan-roeterhadap-pr-678b389e.pdf, diakses 12 Mei 2020)

Tauke, Putri Yuliana., Sri Murni dan Joy E. Tulung. 2017. Pengaruh Kinerja Keuangan Terhadap Nilai Perusahaan Real Estate and Property Yang Terdaftar Di Bursa Efek Indonesia Tahun 2012-2015. Jurnal EMBA Vol.5 No.2 Juni Hal. 919-927.

(https://www.researchgate.net/publication/327666571_PENGARUH_KINERJA_KEUANGA N_TERHADAP_NILAI_PERUSAHAAN_REAL_ESTATE_AND_PROPERTY_YA NG_TERDAFTAR_DI_BURSA_EFEK_INDONESIA_TAHUN_2012-2015 diakses 13 Desember 2020 